\title{
Chemical Blossom Thinners Vary in Their Effect on Sweet Cherry Fruit Set, Yield, Fruit Quality, and Crop Value
}

\author{
Matthew D. Whiting ${ }^{1,3}$, David Ophardt ${ }^{1}$, and James R. McFerson ${ }^{2}$
}

AdDitional Index words. Prunus avium, source-sink relations, blossom thinning, yield, Gisela, rootstock, crop value, organic production

SumMARY. The commercial adoption of the relatively new rootstock 'Gisela 5' (Prunus cerasus L. x P. canescens L.) has been limited in the United States sweet cherry $(P$ avium L. ) industry despite its ability to induce precocity and productivity and reduce scion vigor compared to the standard Mazzard (P. avium). This is due in large part to inadequate crop load management that has led to high yields of small fruit. This paper reports on sweet cherry chemical blossom thinning trials conducted in 2002 and 2003. Two percent ammonium thiosulphate (ATS), $3 \%$ to $4 \%$ vegetable oil emulsion (VOE), and tank mixes of $2 \%$ fish oil $+2.5 \%$ lime sulphur (FOLS) were applied to entire 8- and 9-year-old 'Bing'/'Gisela 5' sweet cherry canopies at about 10\% full bloom (FB) and again at about $90 \%$ FB. In both years, ATS and FOLS reduced fruit set by $66 \%$ to $33 \%$ compared to the control (C). VOE reduced fruit set by $50 \%$ compared to C in 2002 but had no effect in 2003. In 2002, fruit yield was $30 \%$ to $60 \%$ lower from thinned trees. In 2003, fruit yield was unaffected by thinning treatment. In 2002, ATS and FOLS improved fruit soluble solids but had no effect in 2003. VOE did not affect fruit soluble solids in 2002 and reduced fruit soluble solids by $12 \%$, compared to $\mathrm{C}$, in 2003 . In 2002 , each thinning treatment nearly eliminated the yield of the small fruit $(\leq 21.5-\mathrm{mm}$ diameter $)$ and increased yield of large fruit ( $\geq 26.5 \mathrm{~mm}$ ) by more than $400 \%$, compared to C. In 2003 , ATS and FOLS did not affect yield of small fruit but increased the yield of large fruit by $60 \%$. In 2003 , VOE-treated trees yielded $4.3 \mathrm{~kg}$ of small fruit per tree compared to about $0.15 \mathrm{~kg}$ from $\mathrm{C}$, suggesting a phytotoxic response to VOE beyond that which may effect thinning. Compared to C, ATS and FOLS consistently reduced fruit set and improved fruit quality. We conclude that commercially acceptable yields of excellent quality 'Bing' sweet cherries can be grown on size-controlling and precocious rootstocks.

$\mathrm{M}$ ost modern high-density tree fruit production systems rely upon intensive crop load management strategies to produce high yields of quality fruit. For example, apple (Malus $\times$ domestica Borkh.) fruit number per tree (i.e., cluster) is monitored often and modified several times throughout a growing season and crop load management strategies are usually several-tiered. These may include a multiplicity of chemical blossom and postbloom thinners (Byers and Carbaugh, 1991; Dennis, 2000; Westwood, 1993), and hand thinning in the current season, as well as gibberellic acid to reduce (Bradley

\footnotetext{
${ }^{1}$ Washington State University, Irrigated Agriculture Research and Extension Center, 24106 N. Bunn Rd., Prosser, WA 99350.

${ }^{2}$ Washington Tree Fruit Research Commission, 1719 Springwater Ave., Wenatchee, WA 98801.

We are grateful to Elizabeth Hansford and Tammy Killian for their technical assistance and to the Washington Tree Fruit Research Commission for financial support of this research.

${ }^{3}$ To whom reprint requests should be addressed: mdwhiting@wsu.edu
}

and Crane, 1959; Tromp, 1982), or ethephon or naphthaleneacetic acid (NAA) to increase, bloom density in the subsequent season (Byers, 1993; Stover et al., 2002). In contrast, crop load of many stone fruit species (Prunus L.) is reduced primarily by hand thinning, although research has shown potential for chemical thinning, especially for peach [P. persica (L.) Batsch.] (Byers and Lyons, 1985; Southwick et. al., 1996). However, hand thinning is expensive and, due to the high fruit number per tree compared to other stone fruit species, likely not practical for dark sweet cherry (P. avium) cultivars such as 'Bing'.
In the U.S. Pacific Northwest (PNW), sweet cherry cultivars have been grafted predominantly on seedling or vegetatively propagated Mazzard ( $P$. avium), a vigorous, nonprecocious rootstock characterized by low spur/canopy fruit-to-leaf area ratio (F:LA) (Maguylo et al., 2004; Webster and Schmidt, 1996; Whiting et al., 2005). A close negative relationship exists between canopy F:LA and fruit quality (Whiting and Lang, 2004), but spur F:LA appears to be the most important intra-canopy factor affecting fruit quality (Whiting and Ophardt, 2005). Therefore, crop load management has not been a critical issue in traditional sweet cherry orchard systems. Indeed, crop load in Mazzard-rooted trees is usually managed sufficiently by dormant and summer pruning designed primarily to reduce vigor and improve light distribution. However, we have observed that such pruning techniques are insufficient for managing crop load for 1 ) new scion cultivars that are substantially more productive/precocious (and often, but not necessarily, self-fertile) than the dominant traditional PNW cultivar Bing, and especially, 2) new clonal rootstocks, such as the Gisela (Gisela Inc., Giessen, Germany) series, that induce precocity and reduce scion vigor compared to Mazzard (Whiting et al., 2005). Therefore, the development of alternative crop load management techniques will be critical as the PNW sweet cherry industry evolves to higher-efficiency orchard systems based on new cultivars and rootstocks and planted at high densities.

In the PNW, 'Gisela 5' and the more vigorous but equally precocious 'Gisela 6' are 2- to 6-fold more productive on a tree basis and dwarfing, compared to the standard, Mazzard (Whiting et al., 2005). Moreover, trees on these Gisela rootstocks achieve full production several years before those on Mazzard. Whiting and Ophardt (2005) compared potential sweet cherry crop load management tech-

\begin{tabular}{llll}
\hline $\begin{array}{l}\text { Units } \\
\begin{array}{l}\text { To convert U.S. to SI, } \\
\text { multiply by }\end{array}\end{array}$ & U.S. unit & SI unit & $\begin{array}{l}\text { To convert SI to U.S., } \\
\text { multiply by }\end{array}$ \\
\hline 0.3048 & $\mathrm{ft}$ & $\mathrm{m}$ & 3.2808 \\
9.3540 & gal/acre & $\mathrm{L} \cdot \mathrm{ha}^{-1}$ & 0.1069 \\
25.4000 & inch $(\mathrm{es})$ & $\mathrm{mm}$ & 0.0394 \\
0.4536 & $\mathrm{lb}$ & $\mathrm{kg}$ & 2.2046 \\
1.6093 & $\mathrm{mph}$ & $\mathrm{km} \cdot \mathrm{h}^{-1}$ & 0.6214 \\
28.3495 & $\mathrm{OZ}$ & $\mathrm{g}$ & 0.0353 \\
$\left({ }^{\circ} \mathrm{F}-32\right) \div 1.8$ & ${ }^{\circ} \mathrm{F}$ & ${ }^{\circ} \mathrm{C}$ & $\left(1.8 \times{ }^{\circ} \mathrm{C}\right)+32$
\end{tabular}


niques and reported great potential for blossom thinning to reduce fruit number per tree and improve fruit quality and crop value. They reported an 11 -fold increase in the yield of premium size fruit (>26.5-mm diameter) in response to manual blossom thinning of 'Bing' /'Gisela 5' trees. Manual blossom thinning is not a practical crop load management practice for commercial cherry growers, however, and very little research has examined potential chemical blossom thinning agents to date.

The sweet cherry physiology program at Washington State University in Prosser has been field-testing practical strategies for balancing fruit number with canopy area in highdensity orchard systems trials. These include modified pruning, spur thinning, inhibiting flower bud initiation, and chemical blossom thinning. The potential benefits of chemical blossom thinning have been modeled previously (Whiting and Lang, 2004; Whiting and Ophardt, 2005), but no literature has yet reported on practical strategies for achieving balanced cropping targets. The objective of this research was to study the efficacy of several chemical thinning agents on yield and quality of 'Bing' sweet cherry grown on the precocious, productive, and dwarfing rootstock 'Gisela 5'.

\section{Materials and methods}

Plant Material and EXPERIMENTAL DESIGN. 'Bing' sweet cherry trees, planted in Spring 1994 on 'Gisela 5' rootstock and spaced $2.5 \times 5.0 \mathrm{~m}$ in north-south rows, were trained to a Y-trellised, multiple-leader architecture at Washington State University's Roza research orchard in Prosser (lat. $46.2^{\circ} \mathrm{N}$, long. $119.7^{\circ} \mathrm{W}$ ). The soil was a silty loam limited by basalt at a depth of about 1.5 to $2 \mathrm{~m}$. Trees were irrigated with under-tree microsprinklers weekly from mid-April to late October. Standard orchard management practices (irrigation, fertilization, pest control, and dormant pruning) were followed every year.

The experimental orchard was about $\mathrm{I}$ ha and planted with two rows of 'Bing' alternating with one row of 'Rainier' so that pollinizer density was high (33\%). Twenty-four 'Bing' / 'Gisela 5' trees were selected on the basis of uniform vigor and potential cropping density, and were assigned to a completely randomized design with six single-tree replications per treatment. Each experimental tree was within 500 $\mathrm{ft}$ of a beehive. Analyses of variance were conducted using the general linear models (GLM) procedure in SAS (SAS Institute, Cary, N.C.) and means were compared by Fisher's least significant difference (LSD) at 0.05 .

ThinNING TREATMENTS. In 2002 and 2003 , water (C), $2 \%$ ammonium thiosulphate (ATS), a tank-mix of $2 \%$ fish oil $+2.5 \%$ lime sulphur (FOLS), and $3 \%$ vegetable oil emulsion (VOE) were each applied by air-blast sprayer at $200 \mathrm{gal} /$ acre to heavily cropped 8 and 9-year-old 'Bing' / 'Gisela 5' sweet cherry canopies. Test trees were isolated by at least one untreated guard tree to the north and south. Applications were made at about $10 \%$ full bloom (FB) and again at about $90 \% \mathrm{FB}$. Trees received the same treatment in both years.

Fruit SET AND QUALITY. Thinner efficacy was evaluated by determining fruit set on one east-facing and one west-facing limb per tree. Flowers on entire sections of 2-year-old wood $($ minimum of 100 flowers, mean $=$ 158) were counted just prior to the unfolding of the perianth (i.e., "popcorn" stage). Within days of harvest, fruit on these limbs were counted and compared to the flower counts to determine percent fruit set.

At harvest, tree yield was deter-

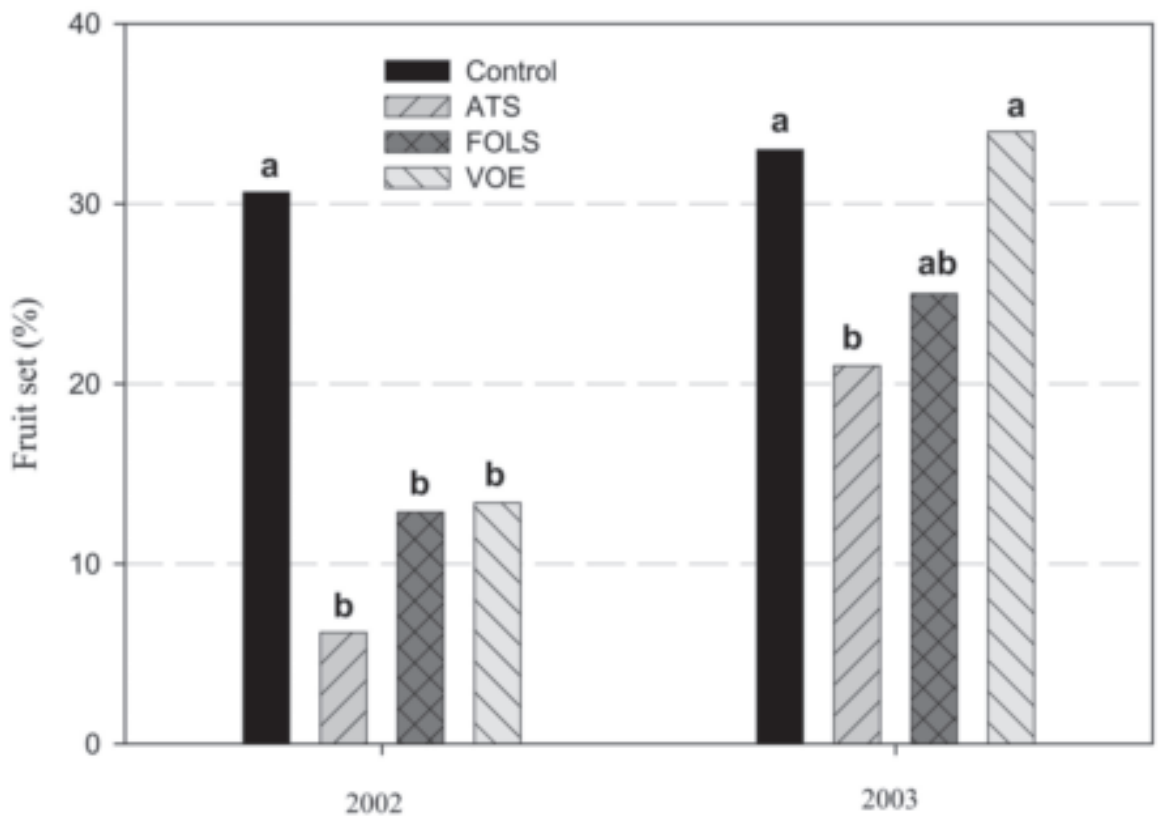

Fig. 1. Effect of chemical blossom thinner on fruit set (percent available flowers) of 8- and 9-year-old 'Bing'/'Gisela 5' sweet cherry trees. Bars with different letters are statistically different within year by Fisher's least significant difference $(P$ $<0.05, \mathrm{n}=8$ ). ATS = ammonium thiosulphate, FOLS = fish oil + lime sulphur, VOE = vegetable oil emulsion. mined in the field. From each tree, randomly selected subsamples of a minimum of 100 fruit were collected and evaluated in the laboratory at room temperature for row-size (an industry size designation related to fruit equatorial diameter), mass, firmness (Firmtech, BioWorks, Stillwater, Okla.), and soluble solids by refractometer. Crop value per tree was calculated from fruit yield and size relationships. Values are based upon average returns for fresh market quality 'Bing' sweet cherries from 2002 and 2003 (G. Allan, personal communication) and include packaging and marketing fees.

\section{Results and discussion}

Fruit SET EFFECTs. Differences in thinning efficacy existed between years and among thinners. In both years, fruit set of untreated $C$ trees was close to $30 \%$ of available flowers (Fig. 1). Interestingly, despite the relatively high pollinizer density (33\%), this is similar to the reported range of fruit set under optimum conditions for many cultivars in Italy (Roversi and Ughini, 1996). In both years, weather conditions were similar and favorable for pollinizer activity and fruit set (i.e., no precipitation, windspeed $<5 \mathrm{mph}$, mean daily air temperature $55^{\circ} \mathrm{F}$ ).

ATS and FOLS consistently reduced fruit set, whereas VOE did 
not. In 2002, each thinning treatment reduced significantly fruit set; compared to C, ATS caused an $80 \%$ reduction and FOLS and VOE caused about $60 \%$ reduction in fruit set (Fig. 1). In 2003, ATS and FOLS reduced fruit set by about $33 \%$ compared to C, and VOE was ineffective. Reasons for these inconsistencies and differences among thinners are not understood fully, but likely related to differences in thinner mode of action, and possibly, tree/flower ontogeny, tree carbon balance, abiotic variables, and spray coverage. Unfortunately, few reports exist evaluating the influence of the pre- and postspray environment (e.g., windspeed, light, vapor pressure deficit, and temperature) and abiotic factors on thinner uptake and efficacy. In apple, thinning efficacy was highest during periods of deficit carbon supplies to fruitlets (Robinson and Lakso, 2004). This response is likely related to photosynthetic inhibition and an increase in dark respiration from certain thinners (Untiedt and Blanke, 2001; Yuan and Greene, 2000).

The specific modes of action of the thinners evaluated herein are not fully understood. Reductions in fruit set likely stem from a combination of reduced net carbon balance (via photosynthetic inhibition and/or increase in dark respiration) and interference with pollination/fertilization from thinner causticity damaging key flower parts (e.g., stigmatic surface) involved in fruit set. We could find no printed report on the effects of chemical blossom thinners on sweet cherry floral morphology/biology, but research in almond has verified that fungicide sprays have direct detrimental effects on stigma morphology (Yi et. al., 2003). VOE may also function by sealing closed the unopened petals, thus disallowing bee visitation and inhibiting pollination (Ju et al., 2001).

The potential to affect sweet cherry fruit set via reductions in net carbon balance may be less important than the physical injury to the floral tissues. In sweet cherry, leaves expand rapidly, their development often concomitant, or within days before or after bloom. Young expanding leaves are carbon sinks, not net distributors of photoassimilates. Therefore, assimilates for initial fruit growth are provided via reserves stored in the perennial woody tissue and not from the leaves developing during applica-

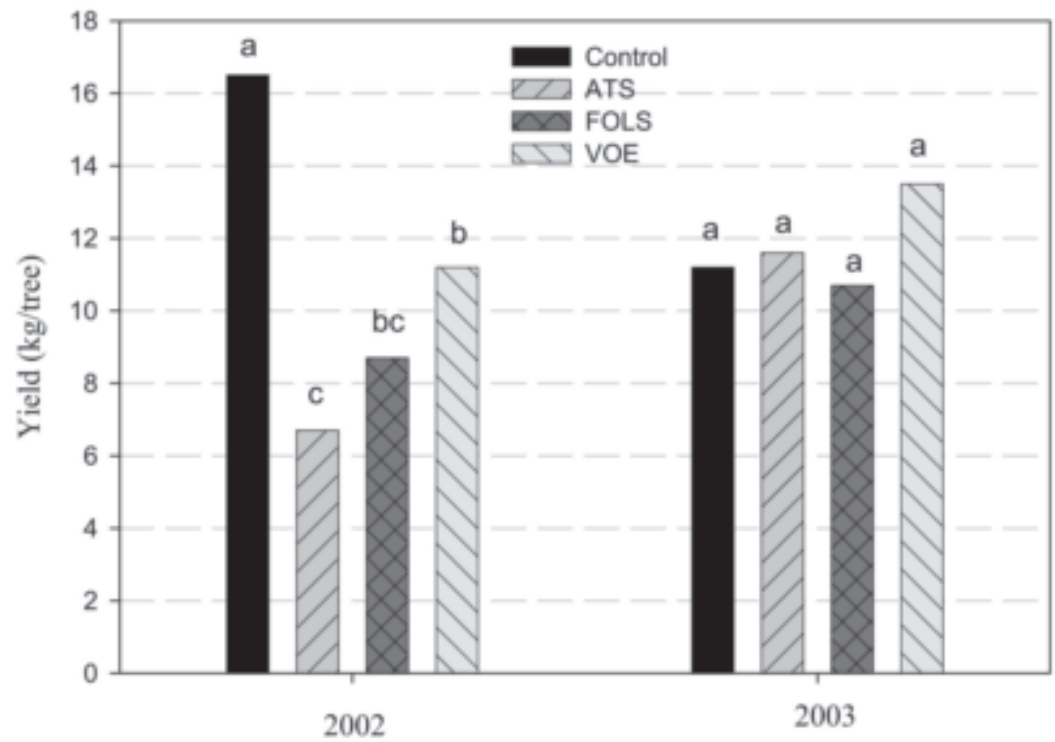

Fig. 2. The effect of blossom thinning treatment on tree yield from 8 - and 9-year-old 'Bing'/'Gisela 5' sweet cherry trees. Bars with different letters are statistically different within year by Fisher's least significant difference $(P<0.05$, $\mathbf{n}=8)$. ATS = ammonium thiosulphate, FOLS = fish oil + lime sulphur, VOE = vegetable oil emulsion, $1 \mathrm{~kg}=2.2046 \mathrm{lb}$.

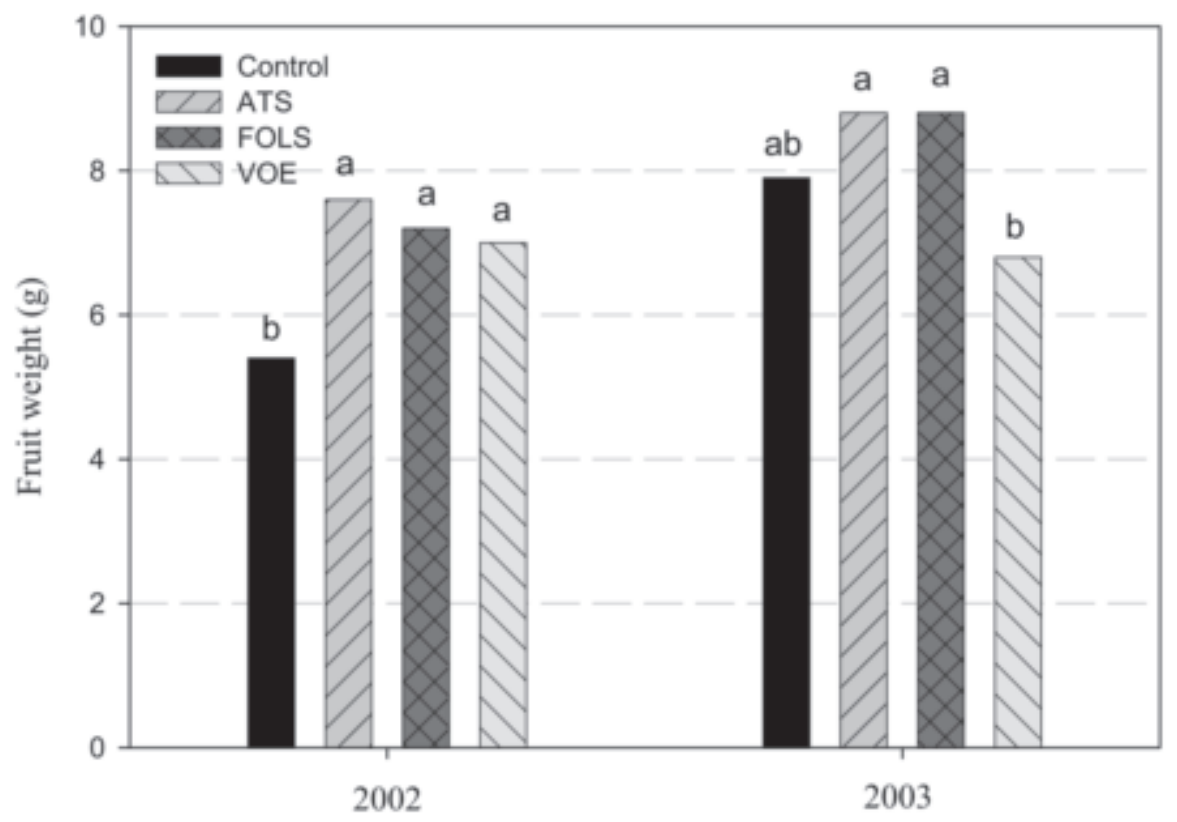

Fig. 3. Effect of chemical blossom thinner on fruit weight from 8- and 9-yearold 'Bing' /'Gisela 5' sweet cherry trees. Bars with different letters are statistically different within year $(P<0.05, \mathrm{n}=8)$. ATS = ammonium thiosulphate, FOLS $=$ fish oil + lime sulphur, $\mathrm{VOE}=$ vegetable oil emulsion, $1 \mathrm{~g}=0.0353 \mathrm{oz}$.

tion. It is therefore less likely that an inhibition of net $\mathrm{CO}_{2}$ exchange from chemical thinner application would affect fruit set. Currently, our lab is investigating thinner mode of action to better understand the relative roles of carbon balance and causticity. Moreover, we are investigating the potential for postbloom thinning of fruitlets by chemical means.
Fruit YIELD AND QUALITY EFFECTS. In 2002, all thinning treatments significantly reduced yield and improved fruit quality compared to unthinned trees (Figs. 2-5). This is due to lower fruit set within thinned trees and, therefore, fewer fruit per tree and reduced competition among fruit for photoassimilates. This general response agrees with earlier reports 


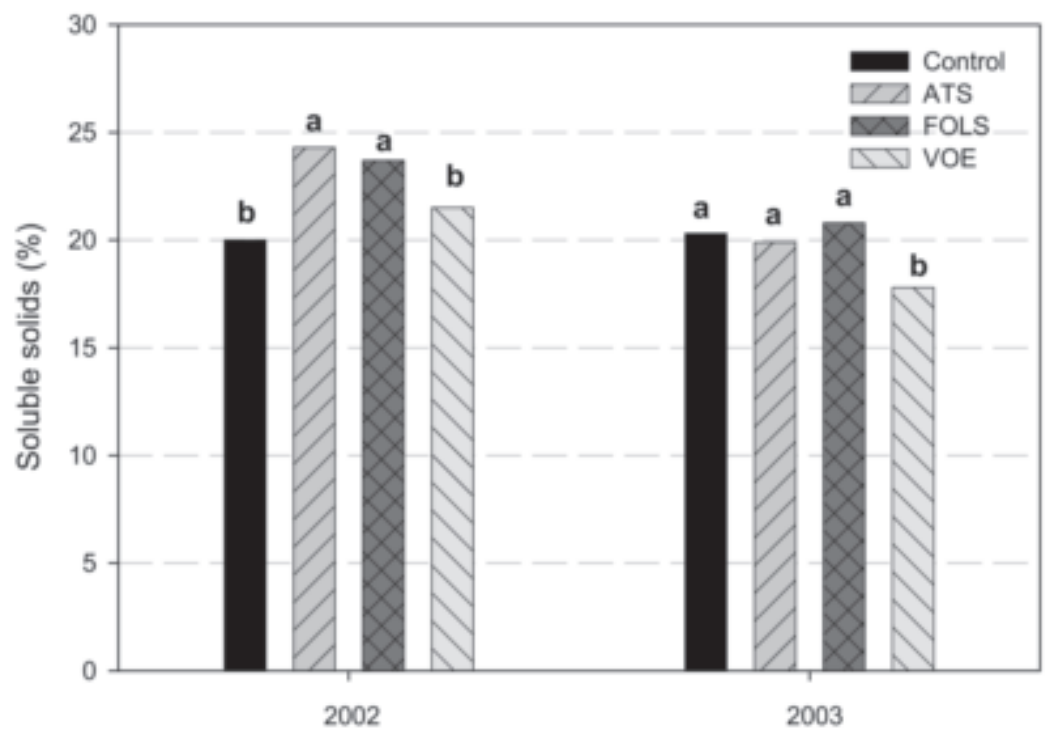

Fig. 4. Effect of chemical blossom thinner on fruit soluble solids from 8- and 9-year-old 'Bing'/'Gisela 5' sweet cherry trees. Bars with different letters are statistically different within year by Fisher's least significant difference $(P<0.05$, $\mathrm{n}=8$ ). ATS = ammonium thiosulphate, FOLS = fish oil + lime sulphur, VOE = vegetable oil emulsion.

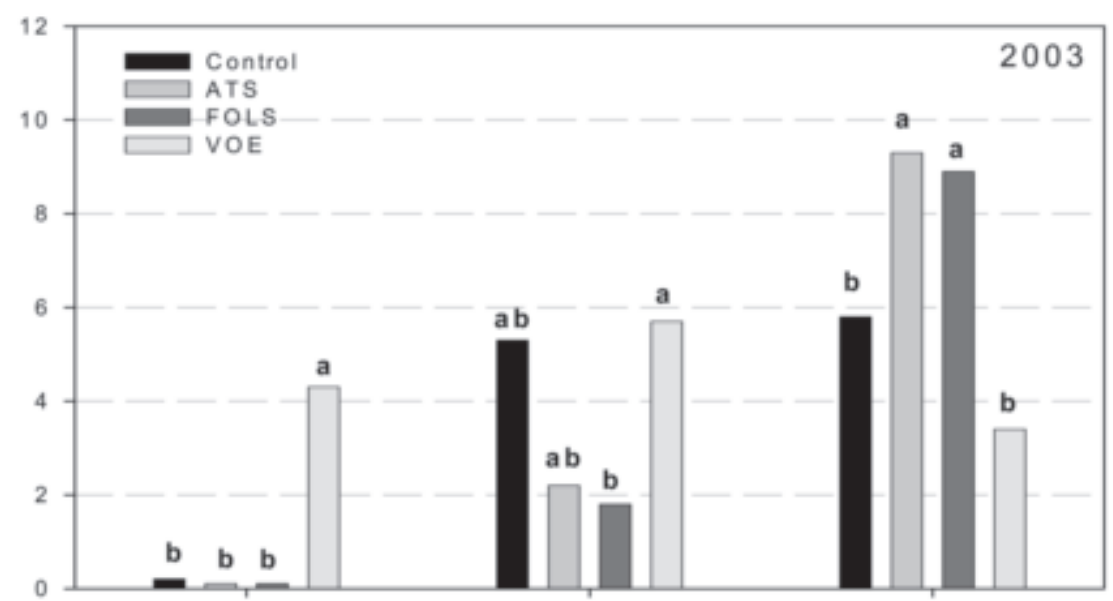

$\frac{\text { 은 }}{\frac{7}{4}}$

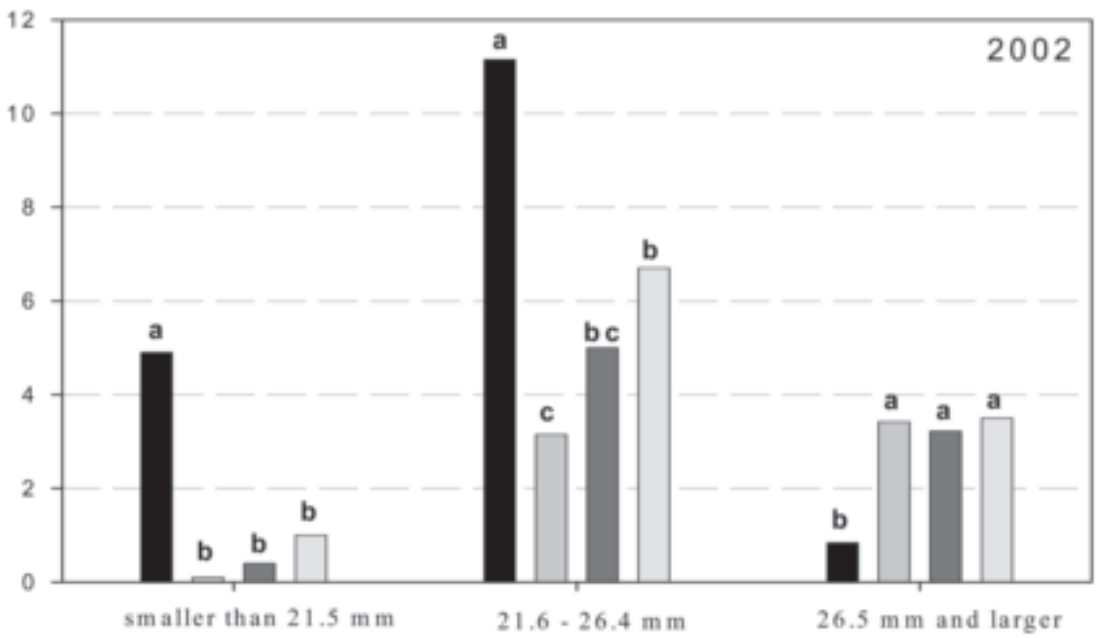

on the negative relation between fruit quality and fruit yield per tree (Roper and Loescher, 1987; Whiting and Lang, 2004). However, reductions in fruit yield were lower, proportionally, than fruit set reductions because of an increase in the weight of remaining, unthinned fruit (Fig. 3).

In 2002, yield was reduced by $60 \%, 50 \%$, and $30 \%$ for ATS, FOLS, and VOE, respectively. This is because mean fruit weight was improved only by $41 \%, 33 \%$, and $30 \%$ for ATS, FOLS, and $\mathrm{VOE}$, respectively - not enough to compensate for significant reductions in fruit set (i.e., fewer fruit per tree). However, in 2003, fruit yield was unaffected by thinning treatment (Fig. 2), despite significant reductions in fruit set with ATS and FOLS (Fig. 1). This suggests that, in 2003 , about a $33 \%$ reduction in fruit set produced a well-balanced crop load because improvements in fruit weight/size compensated fully for there being fewer fruit per tree. By extrapolation, ATS- and FOLS-treated trees bore about 1222 fruit $(11 \mathrm{~kg}$ of 9-g fruit). A previous balanced cropping model for 'Bing'/'Gisela 5' trees suggested 2000 fruit as the optimum fruit number per tree (Whiting and Lang, 2004). This suggests that in 2003 ATS- and FOLS-treated trees were slightly under-cropped, although they had ostensibly less canopy leaf area compared to trees from the previous report and hence, lower carrying capacity. To be sure, this target crop load will vary, depending on tree age, cultivar, rootstock, leafarea, and canopy architecture, among other factors.

In 2002, each thinning treatment nearly eliminated the yield of the smallest fruit $(\leq 21.5 \mathrm{~mm})$ and increased yield of large fruit $(\geq 26.5 \mathrm{~mm})$ by more than $400 \%$, compared to the unthinned C (Fig. 5). Yield of $\leq 21.5$-mm-diameter fruit was $4.9,0.1,0.4$, and $1.0 \mathrm{~kg}$ for C, ATS, FOLS, VOE, respectively. However, FOLS and VOE still yielded only $37 \%$ and $31 \% \geq 26.5-\mathrm{mm}$-diameter fruit, respectively. Only ATS-treated trees yielded a majority of fruit (51\%) in the premium size category. In contrast, C trees yielded only $5 \%$ in the premium category, and 29\% were smaller than 21.5-mm diameter.

In 2003, we observed a different

Fig. 5. Effect of chemical blossom thinner on yield distribution from 8- and 9-year-old 'Bing'/'Gisela 5' sweet cherry trees. Bars with different letters are statistically different within year and size category by Fisher's least significant difference $(P$ $<0.05, \mathrm{n}=8)$. ATS = ammonium thiosulphate, FOLS = fish oil + lime sulphur, VOE = vegetable oil emulsion, $1 \mathrm{~mm}=$ 0.0394 inch, $1 \mathrm{~kg}=2.2046 \mathrm{lb}$. 
response (Fig. 5). Unthinned trees were $32 \%$ lower yielding and produced better-quality fruit compared to the previous year. In fact, there were almost no fruit smaller than $21.5 \mathrm{~mm}$ (about 2\%) and most were $26.5 \mathrm{~mm}$ and larger $(51 \%)$. These data suggest that there were fewer flowers on trees in 2003 because fruit set was no different between years. ATS and FOLS did not reduce the yield of small fruit but did increase the yield of large fruit by $60 \%$, compared to $\mathrm{C}$. In addition, the ATS and FOLS treatments produced about $82 \%$ fruit $\geq 26.5 \mathrm{~mm}$.

In contrast, $\mathrm{VOE}$ was largely ineffective as a thinner in 2003; fruit set was unaffected and trees produced lower-quality fruit than C. For example, VOE-treated trees yielded significantly more small fruit per tree ( 4.3 vs. 0.15 $\mathrm{kg}$ ) and less premium quality fruit (3.4 vs. $5.8 \mathrm{~kg}$ ) compared to the unthinned C (Fig. 5). In addition, fruit soluble solids from VOE-treated trees were 10\% lower than fruit from $\mathrm{C}$ trees (Fig. 4). This yield and fruit quality response is a concern and suggests that VOE exerted a phytotoxic effect beyond that which may cause thinning. We have documented significant reductions in net photosynthesis from VOE application (Lenahan and Whiting, unpublished).

Profitability of any orchard system depends upon fruit yield, quality, price, and expenses involved in planting, maintaining, and harvesting the orchard. In a preliminary analysis, gross crop value was estimated from detailed yield and size data collected in both years (Table 1). The perfectly balanced crop would optimize yield, and maximize crop value per tree or acre. In 2002, estimated gross crop value (dollars/tree) was highest for unthinned $\mathrm{C}$ due to excessive thinning and low yields from treated trees. This analysis highlights a potential pitfall of any chemical thinning program: too great a yield reduction despite improvements in fruit quality and crop value on a weight basis (i.e., dollars $/ \mathrm{kg}$, Table $\mathrm{l}$ ) achieved with thinning. In 2003, crop value per tree and per kilogram from $\mathrm{C}$, ATS, and FOLS was higher than the previous year, reflecting again the overall improvements in fruit quality compared to 2002. The highest crop values were achieved with ATS and FOLS on both a tree $(\sim 34 /$ tree $)$ and weight $(\sim \$ 3.1 / \mathrm{kg})$ basis. These per tree values would translate into gross
Table 1. Estimated effect of chemical thinning program on gross value of 'Bing' sweet cherries.

\begin{tabular}{|c|c|c|c|}
\hline \multirow[b]{2}{*}{ Year } & \multirow[b]{2}{*}{ Treatment $^{\mathrm{z}}$} & \multicolumn{2}{|c|}{ Crop value } \\
\hline & & $\overline{(\$ / \text { tree })^{y}}$ & $(\$ / \mathrm{kg})$ \\
\hline \multirow[t]{4}{*}{2002} & Control & 26.0 & 1.50 \\
\hline & ATS & 17.5 & 2.62 \\
\hline & FOLS & 20.3 & 2.36 \\
\hline & VOE & 24.7 & 2.21 \\
\hline \multirow[t]{4}{*}{2003} & Control & 29.6 & 2.63 \\
\hline & ATS & 35.6 & 3.07 \\
\hline & FOLS & 33.5 & 3.14 \\
\hline & VOE & 23.9 & 1.78 \\
\hline
\end{tabular}

${ }^{{ }^{2} \text { ATS }}=$ ammonium thiosulphate, FOLS $=$ fish oil + lime sulphur, $\mathrm{VOE}=$ vegetable oil emulsion.

${ }^{\prime} \$ 1.00 / \mathrm{kg}=\$ 0.4536 / \mathrm{lb}$.

returns of $\sim \$ 13,260 /$ acre at 390 trees/ acre (i.e., $8 \times 14 \mathrm{ft}$ ). Crop value was the lowest in 2003 from VOE-treated trees, reflecting poor fruit quality.

In conclusion, compared to unthinned trees, ATS and FOLS consistently reduced fruit set and improved fruit quality compared to $\mathrm{C}$, while VOE was inconsistent. However, these results should be interpreted with caution; they are preliminary data from one location and scion/rootstock combination over 2 years. The longterm effects of these blossom thinners on different cultivars, locations, and crop value must be studied before effective recommendations can be made. However, commercially acceptable yields of excellent quality sweet cherries can be grown on size-controlling and precocious rootstocks.

\section{Literature cited}

Bradley, M.V. and J.C Crane. 1959. Gibberellin-induced inhibition of bud development in some species of Prunus. Science 131:825-826.

Byers, R.E. 1993. Controlling growth of bearing apple trees with ethephon. HortScience 28:1103-1105.

Byers, R.E. and D.H. Carbaugh. 1991. Effect of chemical thinning sprays on apple fruit set. Hort Technology 1:41-48.

Byers, R.E. and C.G. Lyons. 1985. Peach flower thinning and possible sites of action of desiccating chemicals. J. Amer. Soc. Hort. Sci. 110:662-667.

Dennis, F.G. 2000. The history of fruit thinning. Plant Growth Regulat. 31:1-16.

Ju, Z., Y. Duan, Z. Ju, and A. Guo. 2001. Corn oil emulsion for early bloom thinning of trees of 'Delicious' apple, 'Feng Huang' peach, and 'Bing' cherry. J. Hort. Sci. Biotechnol. 76:327-331.
Maguylo, K., G.A. Lang, and R.L. Perry. 2004. Rootstock genotype affects flower distribution and density of 'Hedelfinger' sweet cherry and 'Montmorency' sour cherry. Acta Hort. 636:259-266.

Robinson, T.L. and A.N. Lakso. 2004. Between year and within year variation in chemical fruit thinning efficacy of apple during cool springs. Acta Hort. 636:283-294.

Roper, T.R. and W.H. Loescher. 1987. Relationships between leaf area per fruit and fruit quality in 'Bing' sweet cherry. HortScience 22:1273-1276.

Roversi, A. and V. Ughini. 1996. Fruit set in sweet cherry as affected by orchard design and tree structure. Acta Hort. 410:435-441.

Southwick, S.M., K.G. Weis, and J.T. Yeager. 1996. Bloom thinning 'Loadel' cling peach with a surfactant. J. Amer. Soc. Hort. Sci. 121:334-338

Stover, E., M. Fargione, R. Risio, and X. Yang. 2002. Crop load reduction and fruit size following multi-step thinning of 'Empire' apple. HortScience 37:130-133.

Tromp, J. 1982. Flower-bud formation in apple as affected by various gibberellins. J. Hort. Sci. 57:277-282.

Untiedt, R. and M. Blanke. 2001. Effects of fruit thinning agents on apple tree canopy photosynthesis and dark respiration. Plant Growth Regulat. 35:1-9.

Webster, A.D. and H. Schmidt. 1996. Rootstocks for sweet and sour cherries, p. 127-163. In: A.D. Webster and N.E. Looney (eds.). Cherries: Crop physiology, production and uses. CAB Intl., Wallingford, U.K.

Westwood, M.N. 1993. Temperate zone pomology. Timber Press, Portland, Ore.

Whiting, M.D. and G.A. Lang. 2004. 'Bing' sweet cherry on the dwarfing rootstock 'Gisela 5': Thinning affects tree growth and fruit yield and quality but not net $\mathrm{CO}_{2}$ exchange. J. Amer. Soc. Hort. Sci. 129:407-415.

Whiting, M.D. and D. Ophardt. 2005. Comparing novel sweet cherry crop load management strategies. HortScience 40:12711275 .

Whiting, M.D., G.A. Lang, and D. Ophardt. 2005. Rootstock and training system affect sweet cherry growth, yield, and fruit quality. HortScience 40:582-586.

Yi, W., S.E. Law, and H.Y. Wetzstein. 2003. Fungicide sprays can injure the stigmatic surface during receptivity in almond flowers. Ann. Bot. 91:335-341.

Yuan, R. and D.W. Greene. 2000. Benzyladenine as a chemical thinner for 'McIntosh' apples. I. Fruit thinning effects and associated relationships with photosynthesis, assimilate translocation, and nonstructural carbohydrates. J. Amer. Soc. Hort. Sci. 125:169-176. 